https://helda.helsinki.fi

\title{
Becoming Integrateable : Hidden Realities of Integration \\ Policies and Training in Finland
}

\section{Masoud, Ameera}

2021-01-02

Masoud, A , Holm , G \& Brunila , K 2021 , ' Becoming Integrateable : Hidden Realities of Integration Policies and Training in Finland ' , International Journal of Inclusive Education , vol. 25 , no. 1 , pp. 52-65 . https://doi.org/10.1080/13603116.2019.1678725

http://hdl.handle.net/10138/327968

https://doi.org/10.1080/13603116.2019.1678725

unspecified

acceptedVersion

Downloaded from Helda, University of Helsinki institutional repository.

This is an electronic reprint of the original article.

This reprint may differ from the original in pagination and typographic detail.

Please cite the original version. 


\title{
Becoming Integrateable: Hidden Realities of Integration Policies and Training in Finland
}

\section{Masoud, Ameera; Holm, Gunilla; Brunila, Kristiina}

\begin{abstract}
This article scrutinizes the normalised realities behind integration policies and training for refugees and immigrants that are claimed to be inclusive. The 'great narrative' of Finland has been focused on equal opportunity via education and training, which makes it even more important to examine the hidden realities and how such realities affect the integration process. We focus on labour marketoriented integration training, since employment is considered to be the most important element for successful integration and social inclusion. Our data consists of interviews with twenty refugees, five immigrants, six integration professionals and three policy makers, in addition to ethnographic field notes. Through a discursive approach and utilising studies on governmentality, we unveil how governing through integration practices works. The article explores how integration practices that claim to be inclusionary are maintaining forms of exclusion, which becomes a mechanism of exclusionary inclusion. Our analysis shows what refugees and immigrants have to adopt and adapt to as part of their own subjectification in order to become integrateable, and thus includable.
\end{abstract}

\section{Keywords}

Integration, exclusionary inclusion, refugees, immigrants, governmentality, subjectification

\section{Introduction}

Integration policies and training for refugees and immigrants have been developed according to inclusive measures through numerous vocational programmes, innovative projects and other shortterm support systems (Brunila et al. forthcoming; Fernandes 2015; MEAE 2017; Benton 2014). However, there are hidden realities and unintended consequences behind the good intentions of integration policies and training (see Fejes \& Dahlstedt 2018; Miera 2012). This article explores some 
of the hidden realities in integration training targeted at unemployed refugees and immigrants in Finland $^{1}$. We have focused especially on refugees and immigrants being mostly depicted as objects of integration policies, which points to a need for a more bottom-up approach to our examination of integration practices (see Leinonen 2015). Finland is an interesting case as its integration policy is considered to be one of the best internationally (MIPEX 2015). Furthermore, Finland is referred to as a country that provides equal opportunity via education and training, thus it is even more important to examine the hidden realities and how such realities affect the integration process. Integration training is considered to promote social justice and fairness and to prevent exclusion, as demonstrated in the National Core Curriculum for Integration Training for Adult Migrants:

The training promotes social justice, creates conditions for open democracy and welfare and prevents exclusion [...] integration training prepares adult migrants for the operating methods of Finnish society, a sustainable lifestyle and everyday life skills [...] The training encourages them towards interaction between different cultural groups and with the mainstream population. Integration training promotes ethnic relations and does not allow discrimination in any form or by anyone (FNBE 2012, 10)

Considering Finland and other Nordic countries as model countries in their inclusive policies (see Karlsdóttir 2017) could conceal the inequalities that occur in practice. In fact, when looking at policies, we can find that there have been tremendous efforts towards achieving inclusion among certain groups of people through education and early intervention. But in practice, these policies have not achieved their ambitious objectives (Hilt 2015; Vlachou 2004). For instance, the inclusion of refugees and immigrants through education and integration training was a challenge even before the so-called refugee crisis, despite the efforts through policies and their implementation through short

\footnotetext{
${ }^{1}$ Even though the majority of the interviews for this paper were conducted with people who came to Finland as refugees, it is worth noting that once they get their residence permit and begin their integration training, they are considered to be immigrants and students (MEAE 2016; FNBE 2012). Using the term refugees and immigrants interchangeably is dangerous (UNHCR 2018). Throughout this paper we have used the term 'refugee and immigrant' to avoid the risk of denying certain groups of people their agency.
} 
term projects (Kurki 2018; Saarinen \& Jäppinen 2014; Goodman 2010). The biggest challenge in Finland (and elsewhere) is to address refugees' and immigrants' high rates of unemployment and labour market mismatches (FMI 2018; EC 2017a). Therefore, in this article, we focus on labour market-oriented integration training, since employment is considered to be the most important element for successful integration and social inclusion (see Masoud et al. forthcoming; Karlsdóttir 2017). Integration practices are focused on preparing refugees' and immigrants' access to labour markets, because the unemployed 'other' is usually constituted as incapable of fulfilling the requirements of the knowledge-based society and to be in need of interventions to become functionable subjects. Integration policies and practices become the 'noble pursuit' that decide on the measures that could help include the other (Pyykkönen 2007, 199; Schinkel 2013).

The concept of integration has been related to the notion of diversity, and both notions denote difference and 'involve boundary making' as integration becomes a 'governmentality of difference' (Anthias 2013). Thus, integration practices automatically construct certain people as being excluded, deficient, and 'not yet' integrated (Schinkel 2013; Vesterberg 2017). Therefore, refugees and immigrants need to be constructed as people who need integration (Anthias 2013), and should be 'made includable' (Vesterberg 2017). Throughout the process of achieving inclusion, those who are constructed as excluded become positioned through what Vesterberg (2017) calls as the 'rationality of exclusionary inclusion' (see also Diken 2004). Exclusionary inclusion are practices that while claiming to be inclusionary are maintaining forms of exclusion. Such practices become a way to govern refugees and immigrants through integration programmes.

This paper presents analysis of what the integration system and its practices offer as a mechanism towards inclusion of people who are categorised as excluded. We have utilised the concept of governmentality and subjectification to reveal the 'taken for granted' and normalised practices of specific interventions (Dean 2010; Miller \& Rose 2008). This allows us to scrutinise the hidden realities of exclusionary inclusion practices in integration training. In other words, we aim to show 
how governing works as a form of exclusionary inclusion and inclusionary exclusion on refugees and immigrants, and what they must adopt and adapt to as part of their subjectification process in order to become integrateable. It is also crucial to say that governing is multidimensional rather than a form of domination, and is related to the emergence of a specific type of individualism that constructs its own particular subjectification, which in this article is understood as 'integrateable' (see Piñeiro \& Haller 2012).

\section{Integration as Exclusionary Inclusion in EU and Finland}

EU policies concerning integration continue to point out that employment is the fundamental aspect of integration and social inclusion (EC 2017b; 2016). Nonetheless, Penninx \& Garcés-Mascareñas $(2016,14)$ stress the fact that integration is 'the process of becoming an accepted part of society' rather than an 'end situation'. Others have argued that integration as a term and a practice continues to include obligations for refugees and immigrants which risk integration becoming a one-way adaptation and a restrictive process, thus failing to attain inclusion (Anthias 2013; Miera 2012). The terms 'integration' and 'inclusion' have been used interchangeably in policies and research, and both terms refer to creating opportunities for socioeconomic and political participation (Carmel \& Cerami 2011).

In Finland, integration training is implemented according to the Act on the Promotion of Immigrant Integration (2010). This means that all immigrants (including asylum seekers and refugees) who have permanent permission to stay in Finland can participate in integration training. To be eligible, one needs to be an unemployed immigrant registered at the employment office. In a meeting with the employment office (TE), an integration plan is drawn-up for the individual, which according to integration policies should be based on the individual's previous experience and interests. Integration training could include language courses, civic education, vocational training and skilling, and/or career guidance (FMEC 2016). However, successful integration has been measured in relation to the 
ability to find employment (Masoud et al. forthcoming). A recent audit of integration training indicated that it is problematic to base the effectiveness of integration training by utilising employment statistics. The audit recommends that it is important to set a monitoring system on integration training in order to provide adequate information on the effectiveness and quality of the training in relation to individuals' language skills and/or employment (NAOF 2018). The OECD $(2018,30)$ also mentions that there is a need for more information on 'participants, course content, and outcomes'. Thus, our analysis will contribute additional information on the effectiveness of integration training.

The general perception of Finland's integration policy is in line with the perception that the Nordic welfare states are 'advanced' countries in their policies and practices (see Keskinen et al. 2009). The Finnish integration system is built on the premise of equality and equal opportunities. The integration plan drawn up for each individual is seen as one of its strongest traits (Integration Act 2010; Saukkonen 2017; MEAE 2016). Despite that, Kerkkänen (2008) reminds us that integration policy in Finland is guided by a shift of knowledge, skills and attitudes among refugees and immigrants. One of the integration aims is to shape the behaviour of the immigrant to become more Finnish-like (IntkeHernandez \& Holm 2015). This defines how society deals with integrating differences, and creates the idyllic well-integrated citizen as a measure of successful integration, when it is even hard for Finns to reach to such an ideal (Kerkkänen 2008; also Rajas 2012).

One of the goals of Finnish integration policies is "shortening migrants" pathways to education and employment" (FMI 2018, 27). Measures to deal with the increased rates of unemployment among refugees and immigrants, and their prolonged integration training phase, have led to the new controversial activation model (KELA 2018). The activation model states that the unemployed has to be active for a minimum of 65 days, or he/she will face a reduction of $4.65 \%$ of the average support of roughly $€ 600$ per month. While this model concerns anyone who is unemployed, it has increased the pressure among refugees and immigrants who face high levels of discrimination as well as 
difficulties in finding jobs (OECD 2018). It limits them by requiring them to rush into any programme in the integration training, or any temporary job. This constantly positions refugees and immigrants to depend on welfare benefits because of their unstable income situation (see Yijälä \& Nyman 2017). Research has shown how integration training as an activation tool has mostly been unsuccessful in increasing employment rates, with refugees and immigrants remaining in prolonged and overlapping integration training (Kurki et al. 2018; Masoud et al. forthcoming). This is in contrast with integration policies that promise to utilise the individual's previous experiences and skills when developing the integration plan (FMEC 2016). The activation model, integration plan and integration practices become an arena for the provision of activation services, and a mechanism to govern and ensure a desired way of becoming integrated (Pyykkönen 2007).

\section{Integration Policies and Training as a Form of Governing}

This paper utilises a Foucauldian understanding on the concept of governmentality (Dean 2010; Rose 1999; Foucault 1982; 1991). To govern means to shape and reshape the behaviour and aspirations of the subject through mechanisms of how and what the others should be (Foucault 1982; Miller \& Rose 2008). Thus, governmentality carries a meaning that is broader than just the state's control of others through the 'conduct of conduct' (Foucault 1991), to also represent the governing of the self and the way which subjects start to understand themselves (Dean 2010). As a result, governmentality includes 'care of the self' (Dilts 2011), where subjects begin to act according to practices of performativity that represents the desired way of acting (Ball \& Olmedo 2013). Hence, power in the context of governmentality is not only practiced by the state, nor does it start or end with the state (Miller \& Rose 2008). On the contrary, power also produces and shapes subjects, which becomes a form of agency (see Brunila et al. 2017; Ball \& Olmedo 2013).

To understand how integration policies and training work, and why refugees and immigrants end up acting as they are supposed to, we have added the notion of subjectification into our analysis. 
Following Davies (1998) and Foucault (1995) subjectification refers to the construction of the ideal subject, and represents an active process of becoming, through which refugees and immigrants are constantly subjected to, therefore becoming part of their own subjection. The formation of the subject thus depends on external powers. This means that refugees and immigrants may resist those powers, but, at the same time, they also depend on them for their own existence in the process of becoming integrateable subjects (see Kurki et al. 2018). As part of their subjectivity, they need to submit to and master the discursive practices of integration.

\section{Method and Data}

This study is part of an on-going project Interrupting Youth Support Systems in the Ethos of Vulnerability led by Associate Professor Kristiina Brunila and funded by the Academy of Finland, in which various support systems targeted at young adults are interrogated. The empirical scope of this paper comprises ethnographic data produced during 2017 and 2018 by Masoud $^{2}$ including observation notes, and interviews with five immigrants and twenty refugees (aged 20 - 35) who are participating in vocational integration training that lasts from two to three years. Additionally, the data include interviews with three project managers, three teachers/trainers, and a group interview with three policy makers.

The research was conducted at two institutions in Finland. The first institution with funding from the Ministry of Education and Culture had a new programme which specifically targeted young adult refugees and immigrants. The Finnish language skills for those programmes had to be B1 level (based on the common European framework of reference for languages). The integration programmes at the second institution were funded by the city and were established as a response to the refugee inflow in Finland and the prolonged duration of integration training. There was a need to create faster ways to access integration programmes, mainly vocational education. One of those measures was removing

2 Data was collected by Ameera Masoud as part of her PhD research. 
the Finnish language requirement, which is part of Finland's ambitious integration plans as mentioned in a recent blog by the Ministry of Economic Affairs and Employment. Therefore, in the programmes conducted by the second institution, some participants barely knew Finnish while others were more fluent, which constituted a big challenge for the teachers and the participants. The studies in both programmes included practical training. Upon completing the programme, they might be able to work or have work trials, or they could apply to study at a university of applied sciences.

In relation to our analytical perspective, utilising a discursive approach (Foucault, 1972; Bacchi \& Bonham 2014; Brunila et al. 2017) illuminates some of the contradictory and complex ways in which integration as a form of power shapes particular discursive practices about refugees and immigrants and their subjectification. We acknowledge that integration policies and training do not just describe refugees and immigrants but help to create them, both as objects and as subjects. Focusing on governmentality and subjectification in our analysis, permits an examination of the multi-layered integration policies and training that seek to guide the governed subject in becoming integrateable and thus includable. Foucault $(1972,28)$ mentions that while studying discursive fields 'we must show why it could not be other than it was, in what respect it is exclusive of any other, how it assumes, in the midst of others and in relation to them, a place that no other could occupy'. Having followed a discursive approach enabled us to view the structure of the different forms of power connected to integration practices and to investigate their effects on refugees and immigrants. It also revealed how they position themselves in regard to the exclusionary inclusion mechanisms of integration training.

\section{Integration: An Intervention Mechanism towards Social Inclusion}

Equal opportunities and inclusion are promised through participating in integration training (FNBE 2012). We have previously shown how the integration plan that is praised internationally leads to a vicious cycle of training, as refugees and immigrants have been guided to integration programmes that do not suit their previous qualifications and skills (Masoud et al. forthcoming). However, since 
participants in integration training receive social benefits, they are required to take part in integration training, which is part of the 'obligations arising from the [integration] plan' (Integration Act 2010). In return, refugees' and immigrants' subjectification towards becoming integrateable subjects begins. Our analysis will show how integration measures have produced the performing subject who must find a place in integration training, as well as the subject who should 'care for the self' during the work practice.

\section{The Performing Subject}

After the integration plan, the subjectification process continues by finding a study place. This could be quite challenging, especially in Southern Finland, where it could take several months to find a place (MEAE 2016) due to increased number of applicants, or because of rejections. Despite how difficult the process of applying and finding a suitable training programme, our interviewees continuously needed to take up the position of becoming integrateable:

After several rejections to get a study place [after the language courses], I started submitting applications to any vocational programme. Because I just had to be accepted somewhere, in order not to lose my unemployment benefits (Participant 2018)

I was applying for several study places, but I was not accepted ... sometimes they said that my Finnish language is the problem, or my application is not good enough ... I did several entrance examinations for vocational programmes. This went on for around one year. I lost hope, and of course, there is the pressure from the employment office... they keep asking me what I am doing now ... They do not help ... They blame me that I am not doing enough and do not have a study place yet ... Then finally, I found this place, which was a bit different from just applying... (Participant 2018)

On one hand, we can notice that integration practices have discursively constituted refugees and immigrants as governable subjects struggling to find out what they want to become, but that they do 
not have the luxury of waiting and exploring what is best for them. On the other hand, this study place that the aforementioned participant was accepted to, was because of an intervention by a teacher from the integration training programme. The teacher, who is also part of the integration discursive practices, was able to suggest a new way to test applicants' skills. She requested a meeting with those who could not get accepted into a study programme and asked them to do some practical tests rather than basing her decision on written applications. That is how at least five of those who were interviewed managed to get into a vocational programme. While this might offer a solution towards inclusion, we argue that it politicises the subject (see Diken 2004), because each time refugees and immigrants are excluded, they are in need of inclusive measures. These measures re-figure the subject; they become regulated and enabled in this ongoing ambivalent process of submission and mastery. As one interviewee said when she went to do the practical test: 'I kept in mind I had to show how interested I am just because I need to be in a programme. It felt it was my last chance' (Participant 2018).

Throughout the aforementioned extracts and our data, we noticed that participants in integration training begin to establish practices of performativity (Ball \& Olmedo 2013) which is part of their subjectification. To get out of the circle of rejections and avoid losing their benefits, they have to perform in a specific way by becoming governors of their own selves, their interests, and of their own integration. Performativity to be included becomes something that is desired. Non-performing renders individuals as irresponsible (see Ball \& Olmedo 2013), and as not trying hard enough to become integrateable.

However, just because they have managed to start their integration training does not mean that the challenges end or that inclusion is achieved. As one interviewee mentioned, it seems that 'the only criterion to enter these programmes is that you are an immigrant' (Participant 2018). This is contradictory to the policies that state that integration training will help refugees and immigrants interact with the mainstream population (FNBE 2012), or perhaps this is exactly how they are 
expected to interact. They are mostly in programmes with no Finns and with individuals from different educational backgrounds:

In the training there are people from different educational backgrounds and with different levels of Finnish ... Sometimes this is challenging in a group work or in general ... it also gets boring ... I wish the criteria could be like when you apply for university entrance, usually there is a criterion based on your background and suitable certification (Participant 2018)

The above extract subjectifies refugees and immigrants into one category, as subjects who have similar interests and abilities to integrate. This assumption is exclusionary and does not recognise the various potential that individuals possess. This is essential because failure is blamed on the individual and integration officials do not question the fact that subjectivities are the outcomes of current integration practices. One of the integration measures that has been implemented to address the prolonged integration training in Finland was the removal of the language requirement for vocational training. This was not only a challenge to integration participants as could be noticed in the above extract; it has also shaped and reshaped the teacher in integration vocational training, which at the same time reflects on the quality of the training:

I really started to stress about teaching ... I do not know whether I should focus on the basics of the Finnish language, which they might not know well, or to disregard it because they have to be learning the words associated with the vocation. But then I wonder how much they understand when I talk and explain ... some have a higher level of Finnish while others do not know much. There are instances that I can even see some students unable to understand simple words such as table, so then I feel I have to stop and go back from the beginning making sure they understand ... I just cannot imagine how hard it is for the students (Teacher 2017) 
Teachers and integration participants are subjected to the measures of expediting integration and its reforms, through a process of submitting and mastering, even though other teachers mentioned that no one knows if these measures are going to be successful. Also, during the training it was noticed that the Arabic-speaking group tend to sit together, because those who know better Finnish can easily explain in Arabic for those who did not. As one said that 'it is embarrassing to keep interrupting the teacher and say that I do not understand' (Participant 2017). This has caused segregated groups based on their knowledge of Finnish. Those examples show that integration training which claims to be eliminating social exclusion is at the same time reproducing binary constructions and positioning the unemployed refugee and immigrant through a duality of exclusionary inclusion practices (see Vesterberg 2017; Anthias 2013). Refugees and immigrants become targets for the testing of specific measures towards inclusion (no language requirement), and they are left on their own to succeed. Such integration measures lead to the subject acting in a particular way. This way integration training and the ability to become successfully integrateable subjects become a way to test their 'commitment' and 'a test of their loyalty rather than a promise for equitable inclusion' (Schmidtke 2012, 34). Eventually that is why activation measures have been created, as policy makers pointed out:

Immigrants have an integration plan and should be participating in integration training. Guidance for them to find the next training is important, so that they are always active and will not lose benefits ... they should not really worry about the activation model because they have the integration system (...) for those who finished the integration phase then they just have to keep finding other labour market training (Group interview, three policy makers 2018)

Despite the difficulties that refugees and immigrants face, as shown earlier, they are considered to be active in a very specific way. They must keep searching for other training in order not to lose their benefits. Consequently, to become an integrateable subject, one should become positioned as 'at risk', therefore ready to adopt an active, wilful, and able subjectivity (see Rose 1999; Ahmed 2014). 
However, because they are subjected to the integration discursive practices, a typical example of subjectification is what happens when they try to activate and free themselves from dependency on benefits:

... KELA [The Social Insurance Institution] stopped giving me money and cut around 200 euros per month from my benefits, because in a very short period, I managed to get into this vocational course, since I studied Finnish on my own. KELA told me that I have not been going to Finnish language courses. I explained that I did not need language courses, and I feel proud being able to learn a language on my own ... I did not feel valued ... even if you are motivated and active and manage to learn a difficult language on your own ... they just do not allow you to rise up, you are knocked down immediately (Participant 2017)

While the extract above shows how the discursively constituted subject actively managed to submit and master becoming integrateable through studying, such action was sanctioned. Refugees and immigrants must adhere to dominant discursive practices of integration, because when things are done differently, the individuality that is a core factor in integration practices becomes restricted within the system. Even though the participant received benefits from the state, he wanted to prove that this is not what he wants to rely on; he wished to free himself from this bond. In principle, he did everything that integration policies and practices anticipate of him; he has been an active subject and wilful. Our finding is in line with that of Brekke \& Borchgrevink (2007), that welfare generated a normalised way of acting and deciding on what is 'considered normal' and 'acceptable', and what are the acts that are 'problematic and in need of government intervention' (Schmauch 2011). Wilfulness becomes anything related to a 'completion of an action' not essentially individually intentional. It is an action decided by others, but the consequences of the action is referred to the subject (Ahmed 2014). This means that the will to become integrateable should be achieved by being subjected to the 
integration practices. Despite them taking care of their own integration, it seems that it was not done in the right way.

\section{'Care for the self' for Forming Subjects}

After refugees and immigrants have managed to constitute themselves throughout the integration training practices, they are then expected to find an unpaid work placement for a couple of months (see FNBE 2012). It is believed that "early contacts with the world of work support migrants' employment" (FMI 2018, 15). To increase their chances in gaining access to employment, they need to show their willingness to work, and prove their competence. They also need to perform with 'the right attitude and remember to smile' (integration project manager 2017). However, finding a work placement as a mechanism towards inclusion might signal experiences of exclusion (see Vesterberg 2017), alongside other challenges:

I was on my own searching for a place to do my work practice ... no one would give me a place, the teacher rather dumped me into a place where no one even speaks Finnish! The point of such work placements is to develop your Finnish language in a work environment that suits your previous skills or future study path, if you do not have certification. I have a master's degree, and I was begging for a place. Every time employers ask me why I have been unemployed, if I have this kind of experience ... None of them seemed to be interested in that I am part of integration training ... On the contrary, it feels that I am not a reliable person to be hired for a job, since no one has dared to offer me a job! (Participant 2017)

The above extract demonstrates how work practice as an integration measure governs individuals towards a specific form of inclusion. The teacher had to find any place for him, meaning she is also subjected to integration requirements rather than just being a teacher. For refugees and immigrants, being subjected to these integration practices and as people who need integration, they begin to 
understand their subjectification process within the power structures of integration practices. In the above extract, the participant was discouraged because work practice was not a good place to practise the Finnish language, which is one of the main aims of the work practice. He mentioned 'I tried to talk to the integration professional, but she told me to appreciate finding a work placement and take advantage of this opportunity to get a job rather than to improve my language'. Thus, we argue that the fear of remaining excluded discursively shifts the subject into becoming appreciative towards finding an unpaid work placement. Our interviewees had the required qualifications, but this was not enough even when they were applying for an unpaid position. Finding a suitable traineeship is hard and those who were aiming for higher positions did not receive any reply or were constantly rejected (see Saarinen \& Jäppinen 2014). However, it was part of self-responsibility to learn how to deal with the process of becoming integrateable:

Sometimes I was treated in a racist way ... but if I told the teacher every time I faced such problems, it would feel like I was a child. Then the teacher will talk to the one responsible for my work placement, who will not like me anymore ... and would even treat me differently ... so I just have to figure out my way (Participant 2018)

Racism has become something that individuals learn to utilise and becomes part of their own subjectification. The practices of exclusionary inclusion has shifted the individual's way of acting and becoming, through which one learns to 'care for the self'. This is essential as they need to care for their own integration by accepting those challenges without complaining. In the field notes, even when several students tried to bring up this issue, the teacher was sorry to hear this was happening but did not know what the best solution would be. As one participant mentioned 'what a waste of time to go sit and do nothing, it makes you feel like you and your knowledge are not worthy'. These practices oblige the refugee and immigrant who are constructed as excluded, unskilled, and as people who lack something (see Fejes \& Dahlstedt 2018; Masoud et al. forthcoming) to become responsible for their integration and the inequalities they face. As a result, they begin to act according to the 
different possibilities of power relations. Several participants mentioned that they were either not given anything to do, or some of them were always given the role of cleaning rather than practicing their profession. Accordingly, they had to manage their ways of conduct and at the same time challenge these practices:

I had to force myself to take responsibility even if no one was giving me anything related to what my training should be. At first, they only asked me to clean and wash dishes. I had to step up and say that my traineeship is not in cleaning ... no one liked the fact that I spoke up and no one helped to guide me with other tasks ... I just started doing those tasks on my own because I refused to be the cleaner (Participant 2018)

I kept observing what they do and try to catch up. I tried to ask but no one helped ... When I do not know something, I keep asking even if they are busy or do not want to answer ... I am here to learn the practical stuff and if I learned it wrong, then it is my fault that I did not ask (Participant 2018)

The above extracts show how individuals had to push themselves to be able to use their knowledge and even their existence in their work placements. Governing works through making subjects behave according to certain mechanisms, which also becomes what they depend on for their own existence as integrateable subjects. One participant refused to take the position of cleaning and needed to 'care for the self'. She started doing other tasks and mentioned how hard it was to push herself to be that strong. If refugees and immigrants are not given the chance to demonstrate their experience, then integration through work placement is contributing towards a practice of exclusionary inclusion. Hence, for the integration system, our interviewees appear to be included, since they are in a work placement. However, they are excluded from doing any work-related tasks or receiving guidance or the opportunity to be employed. One mentioned, 'I am now doing my third work practice without any job offer after ... I am told that my profile is impressive, and my knowledge could probably be utilised 
in the future ... this future never came'. We also found out that when there were other Finns doing their practical training, they were given details on what they should do, while our interviewees were not, even after they asked for it. What becomes problematic is the fact that different integration measures, such as the integration plan, vocational education, and work practice, have become the only 'right' necessary tools towards inclusion.

\section{Concluding Discussion}

In this article, we have shown how governmentality works on the subjectification of refugees and immigrants through an exclusionary inclusion process. Refugees and immigrants become trapped in the ambivalent process of exclusionary inclusion and inclusionary exclusion. Which means, as long as they are in integration training and work practice, they are considered included even if they are in educational programmes that do not suit their previous experiences and they are facing difficulties finding jobs. They remain excluded and not much is done to investigate the challenges and inequalities that they face during the different measures of integration. Governmentality has allowed us to understand power as non-static, and how refugees and immigrants encounter these power relations. This has also allowed us to view how refugees and immigrants are considered unemployable thus not yet integrated, which has governed them to act under certain mechanisms to become integrateable subjects. When refugees and immigrants are unemployed, they are not perceived as individuals. They have the dual disadvantage of being the other, and unemployed (Schmauch 2011). This dual disadvantage shifts the focus solely towards their ability to get into integration training or work practice and most importantly, to find a job, any job. This perspective denies the idea that they are individuals with a range of potential. In that sense, integration measures become a normalised reality for refugees and immigrants and shape them as subjects in a specific way to achieve inclusion.

Integration as an inclusive measure becomes the way to activate refugees and immigrants in order to achieve social cohesion. An integration system based on equality needs to construct certain people as 
problematic and at risk of exclusion, thus in need of certain measures. Our analysis has shown that integration measures of inclusion contribute towards binary constructions. Difference inevitably needs integration measures, exclusion needs inclusion gestures, and the unemployed needs skilling in order to find employment. Accordingly, what appears to be providing equal opportunities has also meant that integration training participants need to shift their interests and to direct and redirect themselves in a specific way within these binary constructions of integration practices. Unemployed refugees and immigrants and those who do not find a study programme or a job through integration training or after their integration phase, are considered as dis-integrated (see Kurki et al. 2018). Disintegration renders the democracy and equality described in policies impossible. Integration becomes a promising project: it predicts the creation of an included refugee and immigrant, despite that it is not evident who is defined as the well-integrated refugee and immigrant. Integration training provides the space for inclusion, but the individual is responsible for complying and taking charge of freeing the self from dependency on integration training and welfare benefits, mainly through finding a job.

\section{References}

Ahmed, S. 2014. Willful Subjects. New York: Duke University Press

Anthias, F. 2013. "Moving Beyond the Janus Face of Integration and Diversity Discourses: Towards an Intersectional Framing”. The Sociological Review 61: 323-343

Bacchi, C. \& Bonham, J. 2014. "Reclaiming Discursive Practices as an Analytic Focus: Political Implications". Foucault Studies (17): 173-192

Ball, S. \& Olmedo, A. 2013. "Care of the Self, Resistance and Subjectivity Under Neoliberal Governmentalities". Critical Studies in Education 54 (1): 85-96

Benton, M., Sumption, M., Alsvik, K., Fratzke, S., Kuptsch, C., \& Papademetriou, D. 2014. Aiming Higher: Policies to Get Immigrants into Middle-Skilled Work in Europe. Washington, D.C.: Migration Policy Institute.

Brunila, K., Honkasilta, J., Ikävalko, E., Lanas, M., Masoud, A., Mertanen, K. \& Mäkelä, K. Forthcoming. "The Cultivation of Subjectivity of Young People in Youth Support Systems". In The Handbook of Therapeutic Cultures, Nehring, D., Madsen, O.J., Gabanas, E., Mills, C., Kerrigan, D. (eds), London: Routledge. 
Brunila, K., Ikävalko, E., Kurki, T., Masoud, A., Mertanen, K., Mikkola, A., Mäkelä, K. 2017. "Transitions, Justice, and Equity in Education in Finland". Oxford Research Encyclopedia of Education. Oxford University Press.

Carmel, E. \& Cerami, A. 2011. "Governing Migration and Welfare: Institutions and Emotions in the Production of Differential Integration”. In Migration and Welfare in the New Europe. Social Protection and the Challenges of Integration, Carmel, E., Cerami, A., \& Papadopoulos, T. (eds.) Bristol: The Policy Press.

Davies, B. 1998. A Body of Writing 1990-1999. Walnut Creek: AltaMira Press.

Dean, M. 2010. Governmentality: Power and rule in modern society. $2^{\text {nd }}$ ed. London: Sage Publications.

Diken, B. 2004. "From Refugee Camps to Gated Communities: Biopolitics and the End of the City". Citizenship Studies 8 (1): 83-106

Dilts, A. 2011. "From 'Entrepreneur of the Self' to 'Care of the Self': Neo-liberal Governmentality and Foucault's Ethics". Foucault Studies 12: 130-146

EC: European Commission 2016. Action Plan on the Integration of Third Country Nationals. Brussels.

EC: European Commission 2017a. Finland: Highly Educated Migrants' Challenges on the Labour Market. European Website on Integration. https://ec.europa.eu/migrant-integration/news/finlandhighly-educated-migrants-challenges-on-the-labour-market

EC: European Commission 2017b. Integration of Refugees: Commission Joins Forces with Social and Economic Partners [press release] http://europa.eu/rapid/press-release_IP-17-5352_en.htm

Fernandes, A. 2015. “(Dis)Empowering New Immigrants and Refugees through their Participation in Introduction Programs in Sweden, Denmark, and Norway". Journal of Immigrant \& Refugee Studies 13(3): 245-264

Fejes, A. \& Dahlstedt, M. 2018. "Popular Education, Migration and a Discourse of Inclusion”. Studies in the Education of Adults 49 (2): 214-227

Finnish Integration Act 2010. Act on the Promotion of Immigrant Integration (1386/2010). Ministry of Employment and the Economy.

FMEC: Finnish Ministry of Education and Culture 2016. The Educational Tracks and Integration of Immigrants: problematic areas and proposals for actions. Finland 2016:6.

FMI: Finnish Ministry of Interior 2018. Work in Finland - Government Migration Policy Programme to Strengthen Labour Migration. Helsinki 
FNBE: Finnish National Board of Education 2012. National Core Curriculum for Integration Training for Adult Migrants. Helsinki

Foucault, M. 1972. The Archaeology of Knowledge and the Discourse on Language. New York: Pantheon Books.

Foucault, M. 1982. “The Subject and Power”. Critical Inquiry 8(4): 777-795

Foucault, M. 1991. “Governmentality”. In The Foucault Effect: Studies in Governmentality, Burchell G., Gordon, C. and Miller, P. (eds). Chicago: The University of Chicago Press

Goodman, S. 2010. "Integration Requirements for Integration's Sake? Identifying, Categorising and Comparing Civic Integration Policies”. Journal of Ethnic and Migration Studies 36 (5): 753-772

Hilt, L.T. 2015. "Included as Excluded and Excluded as Included: Minority Language Pupils in Norwegian Inclusion Policy”. International Journal of Inclusive Education 19 (2): 165-182

Intke-Hernandez, M., \& Holm, G. 2015. "Migrant stay-at-home mothers learning to eat and live the Finnish way". Nordic Journal of Migration Research 5 (2): 75-82

Karlsdóttir, A., Sigurjónsdóttir, H. R., Ström Hildestrand, Å., \& Cuadrado, A. 2017. Policies and Measures for Speeding up Labour Market Integration of Refugees in the Nordic Region. A knowledge overview. Nordregio Working Paper 2017:8

KELA: The Social Insurance Institution of Finland 2018. "A Letter about the Activation Model" Accessed 1 June 2018. https://www.kela.fi/web/en/news-archive/-/asset_publisher/IN08GY2nIrZo/content/a-letter-aboutthe-activation-model?_101_INSTANCE_3a1vR0IztzeZ_redirect $=\% 2 \mathrm{Fweb} \% 2 \mathrm{Fen}$

Kerkkänen, H. 2008. “Kotouttaminen Kulturisoivan Biovallan Käytäntönä”. Finnish Journal of Ethnicity and Migration, 3 (1): 21-32

Keskinen, S., Tuori, S., Irni, S., Mulinari, D. 2009. "Introduction: Postcolonialism and the Nordic Models of Welfare and Gender". In Complying with Colonialism. Gender, Race and Ethnicity in the Nordic Region, Keskinen, S., Tuori, S., Irni, S., Mulinari, D. (eds), 1-16. Farnham: Ashgate.

Kurki, T. 2018. "Immigrant-ness As (Mis)Fortune? Immigrantisation through Integration Policies and Practices in Education" PhD diss., Helsinki: University of Helsinki.

Kurki, T., Masoud, A., Niemi, A-M., Brunila, K. 2018. "Integration Becoming Business: Marketization of Integration Training for Immigrants". European Educational Research Journal. Special issue on amplifying refugee voices in European educational spaces 17 (2): 233-247.

Leinonen, J. 2015. "Introduction". In Participation, Integration, and Recognition: Changing Pathways to Immigrant Incorporation, Heikkilä, E., Kostiainen, A., Leinonen, J., Söderling, I. (eds.) Institute of Migration Turku Finland. 
Masoud, A., Kurki, T., Brunila, K. Forthcoming. "Learn Skills and Get Employed. Constituting the Employable Refugee Subjectivity through Integration Policies and Training Practices". In Youth on the Move: Tendencies and Tensions in Youth Policies and Practices, Lundahl, L. \& Brunila, K. (eds), Helsinki University Press

MEAE: Ministry of Economic Affairs and Employment in Finland 2016. Government Integration Programme for 2016-2019 and Government Resolution on a Government Integration Programme. Publications of the Ministry of Economic Affairs and Employment 47.

MEAE: Ministry of Economic Affairs and Employment 2017. New Inputs to Boost Immigrants' Employment. Press Release https://tem.fi/en/article/-/asset_publisher/maahanmuuttajientyollistymista-nopeutetaan-uusilla-panostuksilla

Miera, F. 2012. "Not a one-way road? Integration as a concept and as a policy". In European multiculturalisms: Cultural, religious and ethnic challenges, A. Triandafyllidou, T. Modood \& N. Meer (Eds.), 192-212. Edinburgh: Edinburgh University Press,

Miller, P. and Rose, N. 2008. Governing the Present: Administering Economic, Social and Personal Life. Cambridge: Polity Press.

MIPEX 2015. Migrant Integration Policy Index. http://www.mipex.eu/finland

NAOF: National Audit Office of Finland 2018. Conclusions and Recommendations: Integration Training. https://www.vtv.fi/en/publications/integration-training/

OECD 2018. Working Together: Skills and Labour Market Integration of Immigrants and their Children in Finland. Paris: OECD Publishing.

Piñeiro, E \& Haller, J. 2012. "Learning to Live Together-Towards a New Integration Society". In International Handbook of Migration, Minorities and Education. Understanding Cultural and Social Differences in Processes of Learning, Bekerman Z., Geisen T. (eds), 85-100. London: Springer.

Penninx R., \& Garcés-Mascareñas, B. 2016. "The Concept of Integration as an Analytical Tool and as a Policy Concept". In Integration Processes and Policies in Europe: Contexts, Levels and Actors, Garcés-Mascareñas B., Penninx R. (eds), 11-30. London: Springer, Cham

Pyykkönen, M. 2007. "Integrating Governmentality: Administrative Expectations for Immigrant Associations in Finland". Alternatives 32: 197-224

Rajas J. 2012. “Assemblage of Pastoral Power and Sameness. A Governmentality of Integrating Immigrant Women”. Nordic Journal of Migration Research 2 (1): 5-15

Rose N. 1999. Powers of Freedom. Cambridge: Cambridge University Press. 
Saarinen, A. \& Jäppinen, M. 2014. "Political and Labour Market Inclusion of Migrants in Finland". In Contesting Integration, Engendering Migration. Theory and Practice, Anthias, F. \& Pajnik, M. (eds.), 143-162. New York: Palgrave.

Saukkonen, P. 2017. Interplay and Co-Operation Between National and Local Levels in Integration Policy. Case Helsinki, Finland. Working Papers. City of Helsinki

Schinkel, W. 2013. "The Imagination of 'Society' in Measurements of Immigrant Integration”. Ethnic and Racial Studies 36(7): 1142-1161

Schmauch, U. 2011. "Working Hard to Integrate: the Role of Gender in Integration Discourse". In Normalization and 'outsiderhood': Feminist Readings of a Neoliberal Welfare State, Fahlgren S., Johansson A., Mulinari D. (eds.) Book series Rethinking Research and Professional Practices in Terms of Relationality. Subjectivity and Power. Bronwyn Davies (ed.) Bentham Science Publishers.

Schmidtke, O. 2012. Commodifying Migration: Excluding Migrants in Europe's Emerging Social Model. The British Journal of Sociology 63 (1): 31-38

UNHCR 2018. 'Refugees' and 'Migrants' - Frequently Asked Questions. Available at: https://www.refworld.org/docid/56e81c0d4.html [accessed 15 November 2018]

Vesterberg, V. 2017. "Rationalities of Exclusionary Inclusion: Constructing Others While Combating Social Exclusion". Reimagineering the Nation: Essays on Twenty-First-Century Sweden, In Ålund, A; Schierup C-U; Neergaard A. (eds.), 141-163. Frankfurt: PeterLang.

Vlachou, A. 2004. "Education and Inclusive Policy-Making: Implications for Research and Practice. International Journal of Inclusive Education 8 (1): 3-21

Yijälä, A. \& Nyman, M. 2017. Living in Limbo. Qualitative Case Study of Skilled Iraqi Asylum Seekers in Finland. City of Helsinki Urban Facts Research series 2017:1. 